Następnie dr Tomasz Maliszewski zaprezentował fragmenty wywiadu-rzeki, który przeprowadził z prof. L. Mokrzeckim w 2006 r. Portret „Profesora jakiego nie znamy” nakreślony przez referenta rzucił nowe światło na osobowość Jubilata oraz zachęcił zebranych do zapoznania się ze wspomnieniami prof. L. Mokrzeckiego m.in. o rodzime, latach szkolnych i studenckich zamieszczonych w Księdze Pamiątkowej.

W kolejnym punkcie przybyli na Sesje przedstawiciele władz Uniwersytetu Gdańskiego uroczyście wręczyli prof. L. Mokrzeckiemu dedykowaną Mu Księgę Pamiątkową.

Na zakończenie drugiej części Sesji wystąpił Akademicki Chór Uniwersytetu Gdańskiego pod dyrekcją prof. Marcina Tomczaka. Warto zaznaczyć, że obecność na uroczystości chóru nie była przypadkowa, prof. L. Mokrzecki był bowiem jego współzałożycielem i opiekunem już od początku lat $70 . \mathrm{XX}$ w.

Trzecia część Jubileuszu odbyła się w restauracji „Menadżer” w Gdańsku-Jelitkowie, gdzie prof. L. Mokrzecki podjął uroczystym obiadem i poczęstunkiem około stu trzydziestu zaproszonych gości. Te mniej oficjalne warunki stworzyły doskonałą okazję do złożenia Jubilatowi osobistych życzeń i gratulacji, a prof. L. Mokrzeckiemu do podarowania wielu uczestnikom tej części Sesji opatrzonej autografem Księgi Pamiątkowej.

Anna Paszkowska

\title{
Międzynarodowa Konferencja Naukowa pt. „Mężczyzna w rodzinie i społeczeństwie - ewolucja ról w kulturze polskiej i europejskiej od średniowiecza do końca XX wieku”, Ciążeń, 9-11 września 2007
}

Tematyka gender studies od szeregu lat cieszy się ogromnym zainteresowaniem, mającym przełożenie w liczbie publikacji, organizowanych sympozjów naukowych czy w realizowanych projektach badawczych. Problematyka roli kobiety w rodzinie i społeczeństwie, pozycja dziecka w relacjach rodzinnych i na zewnątrz znalazły się również w kręgu zainteresowań naukowych poznańskiego środowiska historyków wychowania, organizujących bądź też współuczestniczących w organizacji konferencji naukowych, tworzących pewną spójność problematyczną i stąd zasługujących na miano cyklicznych.

Tegoroczne spotkanie, które miało miejsce w dawnym pałacu biskupów poznańskich w Ciążeniu, będącym obecnie własnością poznańskiego uniwersytetu miało szczególny charakter, choćby $\mathrm{z}$ racji dużego zainteresowania uczonych reprezentujących niemal wszystkie liczące się ośrodki naukowe w Polsce oraz udziału naukowców z Czech, Słowacji, Słowenii i Ukrainy. Ponadto poszerzono tematykę poruszoną podczas dotychczasowych konferencji, których celem było poznanie pozycji społecznej rodziny i jej członków na przestrzeni wieków - od średniowiecza do współczesności. Przypomnieć warto, że tematami poprzednich spotkań były kobiety (1997 - „Rola i miejsce kobiet 
w edukacji i kulturze polskiej”) i dzieci (druga konferencja z tego cyklu „Dziecko w rodzinie i społeczeństwie" odbyła się w 2002 r., a Zakład był jednym z współorganizatorów), a także rodzice jako pedagodzy - „Powiązania rodzinne wśród twórców polskiej teorii i praktyki edukacyjnej" (2004), w tym roku natomiast uczestnicy zaprezentowali wyniki badań dotyczących pozycji mężczyzny w rodzinie i społeczeństwie. Uzupełnieniem wspomnianych konferencji było również spotkanie naukowców w 1999 r. pt.: „Działalność kobiet na ziemiach polskich na polu oświaty i nauki”.

Nie bez znaczenia był również fakt powiązania omawianej konferencji ze świętowaniem czterdziestej rocznicy powstania Zakładu Historii Wychowania UAM. Z tej okazji odbyła się prezentacja okolicznościowego wydawnictwa pt. Ad novum fructum. $Z$ okazji jubileuszu poznańskich historyków wychowania, zredagowanego przez Wiesława Jamrożka, Krzysztofa Ratajczaka i Dorotę Żołądź-Strzelczyk.

Otwarcia obrad dokonal w imieniu organizatorów prof. Wiesław Jamrożek oraz w imieniu władz Łużyckiej Wyższej Szkoły Humanistycznej - współorganizatora konferencji - mgr Izabela Kumor-Pilarczyk. Ze strony władz UAM głos zabrał Jego Magnificencja Prorektor prof. Janusz Wiśniewski, a władze Wydziału Studiów Edukacyjnych UAM reprezentowała prodziekan prof. Dorota Żołądź-Strzelczyk, która odczytała adres od dziekana prof. Wiesława Ambrozika. Kierownik Zakładu Historii Wychowania, prof. W. Jamrożek dokonał następnie prezentacji dziejów Zakładu oraz księgi jubileuszowej ${ }^{1}$. Z kolei dr K. Ratajczak zaprezentował zebranym dzieje pałacu w Ciążeniu oraz otaczających go ziem, zwłaszcza pobliskiego Lądu i znajdujących się tam cennych obiektów historycznych.

Obradom pierwszego dnia przewodniczył prof. Karol Poznański (Warszawa), a referaty wygłosili prof. Władysława Szulakiewicz (Toruń), która dokonała analizy dorobku naukowego Zakładu z perspektywy własnych badań nad historiografią historyczno-oświatową oraz prof. Krzysztof Jakubiak (Bydgoszcz-Gdańsk), podnosząc kwestie bezpośrednio już związane $\mathrm{z}$ tematyką sympozjum. Uczony przeanalizował postać ojca w rodzinie polskiej na przełomie XIX i XX w., biorąc pod uwagę jego obraz zawarty w piśmiennictwie pedagogicznym i rodzinnym, zwłaszcza na terenie Galicji. Po dyskusji nad referatami uczestnicy obrad wyshuchali występu artystycznego.

Obrady plenarne drugiego dnia międzynarodowego sympozjum otworzył wykład prof. D. Żołądź-Strzelczyk (Poznań) na temat stosunków rodzinnych w dynastii jagiellońskiej, ze szczególnym uwzględnieniem Jagiellonów jako ojców, którzy - jak wykazano $\mathrm{z}$ reguły troszczyli się o swoich potomków, $\mathrm{w}$ tym i z nieprawego łoża. Temat ojcostwa w odniesieniu do realiów Wołynia w XVI i XVII w., opierając się na metodologii gender studies zaprezentowała następnie prof. Irina Woronchuk (Kijów). Autorka zwróciła uwagę na rozdźwięk między źródłami prawnymi, np. w kwestii małżeńskiej a wymową źródeł o charakterze majątkowym, które wskazywały na silną pozycję mężczyzny w związkach małżeńskich wbrew deklaratywnej równości, wskazywanej choćby przez statuty litewskie. W tematyce genderowej pozostawał też referat Edyty Głowackiej-Sobiech (Poznań), która podjęła się zbadania meandrów ponowoczesnej społecznej historii

\footnotetext{
${ }^{1}$ Ad novum fructum. Z okazji jubileuszu poznańskich historyków wychowania, pod red. W. Jamrożka, K. Ratajczaka, D. Żołądź-Strzelczyk, Poznań 2007.
} 
kultury i antropologii historycznej i obrazu mężczyzny zawartego w tekstach pozostających pod wpływem nowej metodologii. Z kolei głos zabrała prof. Jana Bezenšek (Maribor - Słowenia). Tematem interesującego i przyjętego owacyjnie wystąpienia były socjologiczne aspekty przemian roli społecznej mężczyzny jako ojca i po prostu mężczyzny w realiach współczesnej Słowenii. Referat wykazał zaskakujące podobieństwa między sytuacją zamożnego, choć niewielkiego społeczeństwa Republiki Słowenii a problemami dotyczącymi sytuacji w Polsce po przekształceniach społecznych i gospodarczych, związanych transformacją ustrojową, a następnie z wejściem naszego kraju do Unii Europejskiej.

Drugą cześć obrad otworzył wykład prof. Andrzeja Meissnera (Rzeszów) na temat edukacji synów chłopskich na ziemiach polskich w XIX w. Uczony przedstawił szereg interesujących zagadnień na przykładzie źródeł pochodzących z Galicji. Z kolei prof. Josef Pšenak (Bratysława) przybliżył sytuację mężczyzny w rodzinie i w społeczeństwie Słowacji. Kolejnym mówcą był prof. Roman Tomaszewski (Słupsk) prezentujący wyniki badań na temat służby wojskowej jako istotnej funkcji mężczyzny. Referat ukazał ewolucję znaczenia służby wojskowej w XIX i XX stuleciu. Kolejny referat zaprezentowała Joanna Król (Szczecin), która podjęła kwestię obrazu modelu relacji między ojcem a synem w ideologii wychowawczej PRL, koncentrując się na okresie budowy nowej ideologii w latach 1948-1956. Plenarną sesję zakończyło wystąpienie prof. Jaroslava Oberuča (Žilina) na temat roli mężczyzny w rodzinie słowackiej. Po dyskusji nad przedstawionymi referatami zebrani udali się na zwiedzanie pałacu oraz cennych zbiorów masoników zebranych przez Bibliotekę Uniwersytecką w Poznaniu. Zawartość obszernej i unikatowej kolekcji przybliżył prof. Jaromir Jeschke, wytrawny znawca problematyki literatury wolnomularskiej.

Dalszą czę́ść obrad zorganizowano w sekcjach tematycznych poświęconych mężczyźnie w rodzinie i społeczeństwie. Podkreślić warto, że moderatorami byli wybitni uczeni: prof. Kalina Bartnicka (Warszawa), prof. Irena Szybiak (Warszawa), prof. Lech Mokrzecki (Gdańsk). W sekcji pierwszej „Mężczyzna w rodzinie” wystąpili Renata Bednarz-Grzybek (Lublin), prezentująca wyniki swej kwerendy zawartości wybranych czasopism wydawanych w Królestwie Polskim w latach 1864-1905 na temat mężczyzny jako partnera kobiety w małżeństwie; Zbigniew Dziemianko (Poznań), mówiący o postrzeganiu oficerów jako mężów i ojców w społeczeństwie II Rzeczypospolitej; Andrzej Kusztelak (Poznań), prezentujący zapisy Katechizmu Kościoła Katolickiego na temat wzoru i ideału ojcostwa. Katarzyna Kabacińska (Poznań) podjęła temat ojca w świetle pamiętników polskich z XVIII w., a Justyna Gulczyńska (Poznań) dokonała analizy roli ojca w edukacji szkolnej dzieci w okresie II RP, posługując się przykładami szkół średnich ogólnokształcących w Poznaniu. Z kolei Kamilla Łozowska-Marcinkowska (Poznań) przedstawiła wnioski na temat ideału męskości wypływające $\mathrm{z}$ analizy zawartości popularnego w latach 30. XX w. czasopisma dla mężczyzn „Współczesny Pan”. Następnie wysłuchano referatu Vilmy-Aliny Bezenšek (Maribor) pt. „Some judical aspects of fatherhood after termination of marriage or common marriage deals" wygłoszonego przez J. Bezenšek. Kolejny koreferat przedstawiły Iwona Chmura-Rutkowska (Poznań) i Joanna Ostrouch (Olsztyn). Autorki zaprezentowały wyniki swych badań socjologicznych na temat odczuwania starości przez współczesnych ojców w kontekście przemian cywilizacyjnych koń- 
ca XX w. Głos następnie zabrał Tomasz Fetzki (Żary), omawiając różne aspekty związane $\mathrm{z}$ wychowaniem dzieci niepełnosprawnych. Obrady zakończyło wystąpienie Piotra Perkowskiego (Gdańsk), poświęcone analizie sytuacji mężczyzny w społecznych rolach ojca i męża w realiach Polski Ludowej.

Obrady sekcji drugiej przebiegały pod hasłem „Mężczyzna w społeczeństwie", a otworzył je referat Adama Fijałkowskiego (Warszawa) na temat roli uczonego i wychowawcy w średniowiecznym społeczeństwie i właściwej niemożności pogodzenia obowiązków naukowych $\mathrm{z}$ posiadaniem potomstwa. Krzysztof Ratajczak (Poznań) zaprezentował postać księcia Kazimierza Odnowiciela jako ojca narodu i głowę rodziny w świetle polskich źródeł narracyjnych z XII-XIV w. Uczestnicy sympozjum wysłuchali następnie wystąpienia Ryszarda Ślęczki i Andrzeja Klisia (Kraków) na temat postrzegania ojcostwa w galicyjskiej teorii pedagogicznej i praktyce szkolnej. Agnieszka Jakuboszczak (Poznań) przedstawiła z kolei obraz mężczyzny zawarty w osiemnastowiecznych źródłach polskich, których autorkami były kobiety, a Ewa Barnaś-Baran (Rzeszów) podzieliła się spostrzeżeniami na temat działalności społecznikowskiej w dziewiętnastowiecznym Krakowie. Agnieszka Wałęga (Toruń) skupiła się natomiast na analizie polskiej literatury pedagogicznej XIX w. i zawartego w niej obrazu ojca, wychowawcy i nauczyciela. Poglądy ówczesnych emancypantek na temat wychowania mężczyzn na przykładzie opinii wygłaszanych przez Izę Moszczeńską omówiła Anna Gołębiewska (Warszawa), natomiast Małgorzata Posłuszna (Poznań) dokonała prezentacji roli ojca w życiu synów na przykładzie środowiska wiejskiego II Rzeczpospolitej. Wysłuchano również referatu Tadeusza Kordylewskiego (Żary), poświęconego analizie roli męża i partnera życiowego w literaturze pięknej.

Trzeciego dnia konferencji odbyło się zwiedzanie zespołu pocysterskiego: klasztoru i kościoła w Lądzie oraz położonej w pobliżu rekonstrukcji grodu piastowskiego, na terenie której odbywa się od kilku lat międzynarodowy festiwal kultury słowiańskiej i cysterskiej. Podczas obrad plenarnych natomiast wysłuchano szeregu interesujących referatów. Pierwszym z prelegentów był prof. Josef Lipnik (Maribor), który przedstawił wykład pt. "Zwei Fater Familie in zwei Romanen". Następnie głos zabrała prof. Daniela Lahe (Maribor), omawiając rolę ojca $\mathrm{w}$ wychowaniu dzieci w społeczeństwie ponowoczesnym („Father's role in children upbringing in the post-modern society). Referat Anny Mamulskiej (Leszno) dotyczył natomiast dziewiętnastowiecznej prasy dla dzieci i zawartego weń obrazu ówczesnego mężczyzny. Zbliżoną tematykę zaprezentowała też Monika Nawrot-Borowska (Bydgoszcz), analizując obraz mężczyzny zawarty w wybranych pamiętnikach polskich rodzin ziemiańskich, pochodzących z lat 1850-1914. W okres Drugiej Rzeczypospolitej przeniósł słuchaczy referat Kamili Juchcińskiej-Giłki (Bydgoszcz). Autorka wyzyskała dla swych badań pamiętniki z pierwszej połowy XX w., poszukując w nich wspomnień odnoszących się do mężczyzn - ojców. Wystąpienie Anny Kołodziej (Poznań) dotyczyło z kolei harcerskich metod wychowawczych i ich wpływu na życie mężczyzn niegdyś związanych z ruchem harcerskim. Czasów najnowszych dotyczył zamykający obrady referat Joanny Surlejewskiej (Łódź) pt. „Mężczyzna, ojciec, opiekun rola ojca w XXI wieku".

Podczas obrad zaprezentowano lub zgłoszono do druku ponad sześćdziesiąt referatów, odbyło się szereg dyskusji naukowych. Warto podkreślić na koniec szeroki odzew 
środowisk naukowych polskich i z krajów sąsiednich oraz fakt interdyscyplinarności obrad, wśród prelegentów byli bowiem historycy wychowania, historycy, socjologowie, pedagogowie i literaturoznawcy. Z przyczyn losowych na obrady nie zdołała dotrzeć część prelegentów, ich wystąpienia zostaną jednak dołączone do materiałów konferencji, które ukażą się drukiem.

Krzysztof Ratajczak

\section{Międzynarodowa konferencja ,Szkolnictwo pijarskie w czasach minionych a współczesne problemy edukacji historycznej". (Kazimierz Dolny 15-17 X 2007)}

W dniach 15-17 października 2007 r. w Kazimierzu Dolnym odbyła się międzynarodowa konferencja naukowa pt. „Szkolnictwo pijarskie w czasach minionych a współczesne problemy edukacji historycznej". Została ona zorganizowana przez Zakład Dydaktyki Historii UMCS w Lublinie wraz z Polską Prowincją Zakonu Pijarów w związku z przypadającą w 2007 r. 450 rocznicą urodzin św. Józefa Kalasancjusza, twórcy pierwszej w Europie szkoły powszechnej oraz założyciela zakonu pijarów. Dodatkową motywacją do organizacji konferencji było ogłoszenie roku 2007 przez ministra edukacji narodowej Rokiem św. Józefa Kalasancjusza.

Uczestnikami zjazdu byli przedstawiciele polskich ośrodków akademickich z Warszawy, Gdańska, Bydgoszczy, Wrocławia, Opola, Katowic, Krakowa, Rzeszowa, Zielonej Góry, Torunia i Lublina. Na konferencję przybyli także goście zagraniczni z Czech i Słowacji zajmujący się działalnością oświatową i kulturalną zakonu pijarów oraz problemami współczesnej dydaktyki.

Spotkanie zainaugurował dziekan Wydziału Humanistycznego UMCS, prof. Henryk Gmiterek oraz przedstawiciel organizatorów prof. Krystyna Wróbel-Lipowa. Obrady rozpoczęła sesja plenarna, której przewodniczyli prof. Lech Mokrzecki, prof. Janusz Rulka i o. dr Henryk Bogdziewicz SP. Na początku o. Edwarda Kryściaka z Polskiej Prowincji Zakonu Pijarów przedstawił sylwetkę św. Józefa Kalasancjusza. Przypomniano także postać i działalność najwybitniejszego przedstawiciela zakonu pijarów w Polsce ks. S. Konarskiego. Prof. Czesław Nowarski zaprezentował poglądy ks. S. Konarskiego na temat kształcenia i wychowania młodzieży, podkreślając ich aktualność. Natomiast prof. Krystyna Wróbel-Lipowa przybliżyła działalność Collegium Nobilium za czasów S. Konarskiego jako szkoły służącej wychowaniu patriotycznemu i obywatelskiemu. W szeroką problematykę historii wychowania jako przedmiotu kształcenia pedagogicznego wprowadzili uczestników konferencji profesorowie Wiesław Jamrożek i Krzysztof Jakubiak, przedstawiając tradycje nauczania tego przedmiotu, stan obecny i jego przyszłość.

Następnie uczestnicy udali się do Opola Lubelskiego - miejscowości związanej z działalnością zakonu pijarów w XVIII-XIX w. Tutaj po uroczystej mszy św. odprawionej przez ojców pijarów oraz zwiedzeniu kościoła popijarskiego, kontynuowano obrady 